\title{
Environmental and occupational respiratory diseases - 1061. The change of eosinophil, serum level of ECP, and interleukin-5 during mycoplasma pneumoniae infection in atopic children
}

\author{
Jae-Won Oh*, Dong-Hoon Han, Ha-Baik Lee \\ From 2nd WAO International Scientific Conference (WISC 2012) \\ Hyderabad, India. 6-9 December 2012
}

\section{Background}

A number of studies have outlined mechanisms by which mycoplasma infection may promote allergic lung inflammation. In addition, there is increasing evidence from human studies suggesting that mycoplasma infection contribute to asthma exacerbations, and severity with the change of cytokines. The present study evaluated the change of serum levels of eosinophil count, eosinophil cationic protein, and interleukin-5 in atopic children with Mycoplasma pneumonia infection.

\section{Methods}

We recruited 145 children including 45 atopic children with mycoplasma pneumonia (Group 1), 39 non-atopic children with mycoplasma pneumonia (Group 2), 35 children with viral pneumonia (group 3), 26 non-atopic children with viral pneumonia with mycoplasma infection (Group 4). The change of total eosinophil count, serum levels of interleukin (IL)-5, eosinophil cationic protein were measured at admission and at recovery for each group by using commercial ELISA.

\section{Results}

The serum level of IL-5 at admission was increased at recovery in group $1(114 \pm 51.1 \mathrm{pg} / \mathrm{mL}$ at admission, $143.2 \pm 68.4 \mathrm{pg} / \mathrm{mL}$ at recovery). However, Buserum eosinophil cationic protein concentrations were increased at clinical recovery compared to the mean serum concentration at admission $(49.5 \mathrm{pg} / \mathrm{mL}$ at admission, $37.9 \mathrm{pg} / \mathrm{mL}$ at recovery in group $1 ; 38.2 \mathrm{pg} / \mathrm{mL}$ at admission, $27.8 \mathrm{pg} / \mathrm{mL}$ at recovery).

Pediatrics, Hanyang University, Seoul, South Korea

\section{Conclusions}

The outcomes of the present study implied changes of eosinophil and its mediators during Mycoplasma infection may be associated with the mechanism by which the Mycoplasma pneumoniae contribute to the development of airway hypersensitivity.

Published: 23 April 2013

doi:10.1186/1939-4551-6-S1-P59

Cite this article as: Oh et al:: Environmental and occupational respiratory diseases - 1061. The change of eosinophil, serum level of ECP, and interleukin-5 during mycoplasma pneumoniae infection in atopic children. World Allergy Organization Journal 2013 6(Suppl 1):P59.
Submit your next manuscript to BioMed Central and take full advantage of:

- Convenient online submission

- Thorough peer review

- No space constraints or color figure charges

- Immediate publication on acceptance

- Inclusion in PubMed, CAS, Scopus and Google Scholar

- Research which is freely available for redistribution 